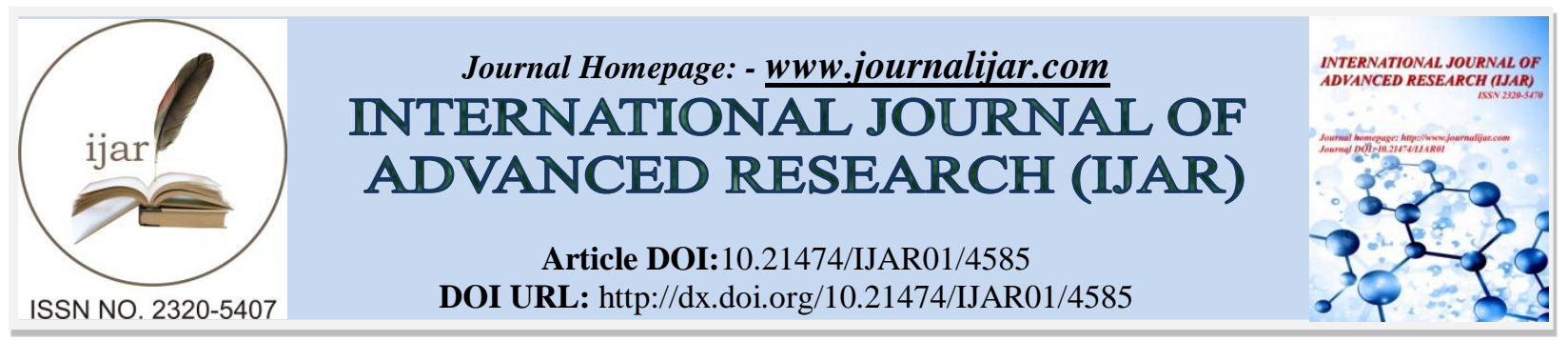

RESEARCH ARTICLE

\title{
STUDIES ON POLLEN VIABILITY OF PAPAYA (Carica papaya (L.) INFECTED BY PAPAYA RING SPOT VIRUS (PRSV).
}

Ravindra Kumar Pandey. P.G.Department of Botany (Plant Pathology Lab)M.L.K.P.G.College Balrampur (U.P.) 271201.

\section{Manuscript Info}

\section{Manuscript History}

Received: 23 April 2017

Final Accepted: 25 May 2017

Published: June 2017

Key words:-

Pollen viability, Post meiotic,

Microsporogenesis, PRSV.

\section{Abstract}

Carica papaya $(\mathrm{L}$.) is infected by a number of diseases caused by fungi ,bacteria and viruses. Among these ring spot disease caused by Papaya Ring Spot Virus (PRSV) is common and most serious disease recorded from several part of the country. The deviations in meiotic studies specially microsporogenesis leads to infertility of pollen due to deviations in meiotic and post meiotic behaviour of cell division processes that leads to chromosomal aberrations most commonly as sticky chromosome, laggerd chromosome and deviations in meiotic index. This reduction in gametic fertility causes loss in quantity of the fruit. The present study deals with comparative study of post meiotic behaviour between healthy and diseased plants that shows deviations at different stages of microsporogenesis that leads to pollen sterility.

Copy Right, IJAR, 2017,. All rights reserved.

\section{Introduction:-}

Papaya (Carica papaya L.) is a tropical and subtropical crop widely cultivated for edible fruits belonging to the family Caricaceae. The exact area of origin is unknown; the papaya is believed to be native to tropical America, perhaps in southern Mexico and neighbouring Central America. The papaya is regarded as a fair source of iron and calcium; a good source of vitamins A, B and an excellent source of vitamin C (ascorbic acid). In India it is commercially grown in many states either as commercial crop or as kitchen garden plant.

Papaya is one of the few rapidly growing and heavily yielding fruit trees. In the peninsular region it bears fruits throughout the year, while under north Indian conditions it is in fruit for about four month beginning from January. Papaya plants are affected by some fungi from seedling to fruit, that reduces the viability of plant and fruit numbers and quality. Except fungal diseases viral diseases also affect from foliar to fruiting stages (Leaf curl and ring spot diseases). Trees affected do not die immediately but their fruit bearing capacity is diminished.

Papaya (C. papaya (L.) is an important fruit crop whose knowledge is still incipient in some areas, specially the basic research that can contribute to its genetic breeding. One of the major problems of this crop is its susceptibility to mosaic virus.

Plants infected by PRSV develop a range of symptoms including ringed spots on the fruit, for which the virus is named. Other symptoms include mosaic colouration and chlorosis of the leaves, streaks on petioles and the upper part of the trunk and shape distortion of young leaves. The plants grow more slowly and become stunted. Plants infected within a few months of planting usually do not produce mature fruit, but those infected later can produce a smaller yield of lower quality papaya.

Corresponding Author:-Ravindra Kumar Pandey.

Address:-P.G.Department of Botany (Plant Pathology Lab)M.L.K.P.G.College Balrampur (U.P.) 271201. 


\section{Materials and Methods:-}

The papaya seedlings will be raised from the seed of different varieties of papaya taken from NBPGR New, Delhi. Seedlings were raised in earthen pods of 6 inch diameter filled with mixture of soil and farm yard manure $(1: 1 \mathrm{w} / \mathrm{w})$. The soil mixture will be sterilized before raising the plant in it. All the experiment will be conducted in a insect proof chamber under normal day light. The plants were grown in a greenhouse in the campus of Botany Department, M L.P.G.College Balrampur.

Virus inoculum taken from virus maintained in the green house of the Botany Department by trituration of frozen leaves of papaya plants seedlings showing mosaic symptoms. Inoculation of leaves was carried out by rubbing with finger after their being dusted with carborandum as described by Rawlinsand Tompkins, (1936). The two month old plant will be sap inoculated the plant showing typical diseased symptoms will be selected after 25 days of inoculation.

At flowering, male plants were identified and labelled for the study. To study the chromosome association, chiasma frequency and meiotic abnormalities,young flower buds of suitable sizes from both normal and viral infected plants were collected from $9.00 \mathrm{a}$ a.m. to $11.00 \mathrm{a} . \mathrm{m}$. These were fixed in 1: 3 acetoalcohol to which a small amount of ferric acetate $(1 \mathrm{~g}$ in $500 \mathrm{ml}$ acetoalcohol) was added imparting a straw colour. After 48 hours of fixation young flower buds were rinsed with distilled water and they were preserved in $70 \%$ ethanol and kept in a refrigerator till used. Temporary slides were prepared from suitable anthers with $2 \%$ acetocarmine by using smear technique. (Alexander, M. P. (1969).

To study pollen sterility, the mature anthers of both normal and virus infected plants were collected at the time of anthesis. The anthers were fixed in $70 \%$ ethanol directly and kept in refrigerator till used. Temporary slides were prepared from mature anthers by using $1 \%$ acetocarmine smear technique The slides were prepared by squashing the anthers in drops of $1 \%$ acetic carmine solution, the debris were removed and the slides sealed for observation

\section{Results and observations:-}

Carica papaya (L.) has $2 \mathrm{n}=18$ chromosomes and no unpaired chromosomes were observed. Thus, there is no evidence of sexual heteromorphic chromosomes. The different meiotic stages were observed, paying particular attention to the prophase I stage and to possible irregularities. Any abnormalities such as lagging chromosomes, sticky chromosomes, and precocious segregation, among others, were registered.

The chromosome pairing studied in pollen mother cells (PMCs) at diakinesis in diseased and healthy plants at different intervals. Both diseased and healthy plant showed normal pairing of chromosome at pachytene with 9 bivalent $(2 \mathrm{n}=18)$, but different associations were observed at diakinesis in diseased and healthy plants at later stage of infection. In diseased plants multivalent configurations are more than healthy plants. Following configurations were observed in diseased and healthy plants.

In meiosis I and meiosis II laggard chromosome were observed chromosome bridges at anaphase I and II were also observed in both diseased and healthy plants but their percentage varied. Details of the findings are presented in table-1.

Details of the result obtained are presented in table no 1, 2 and 3. According to that the pollen viability was $96.60 \%$ and $73.96 \%$ on an average in healthy and diseased plants respectively. Two types of sterile pollens were observed: (a) empty where only the wall reacted to the stain, indicating absence or only traces of cytoplasm; (b). Shrunken where both the wall and cytoplasm reacted to the stain, but a space was observed between the plasmatic membrane and the cell wall, accompanied by cytoplasm contraction. The pollen grains of empty type were found in greater quantity and were on average $58.22 \%$ in healthy plants and $64.5 \%$ in diseased plants of the total sterile pollen grains observed (table 1 and 2). The size of viable pollen grains varied from 56 to 70 micron. (60.20 \pm 1.96 micron) where as size of sterile empty pollen measuring from 20 to 55 micron. (44.50 \pm 8.22 micron) and shrunken sterile pollen size vary from $45-65$ micron $(53.26 \pm 4.37$ micron). 


\section{Discussion:-}

Kostoff (1933) reported nonfunctional pollen and ovule in some mosaic diseased tobacco varieties and Nicotiana sp. In the present investigation more nonfunctional pollens were found in diseased plants $22-32 \%$ infected by various strains of C.G.M.M.V. in comparison to healthy ones. In most severely attacked buds a few or many PMCs occasionally degenerated during diakinesis. This degeneration is due to abnormalities in the reduction division. Which is due to certain abnormal processes is caused by the virus. Similar observations earlier reported by Kostoff (1933) in some mosaic disease of tobacco and tomato.

Cytological irregularities following virus attack on plants have been reported by some workers. Wilkinson (1953) found several cytological abnormalities in tomato infected with virus. Diaz and Pavan(1965) reported anomalies like increased cell and chromosome size associated with fragmentation of chromosomes. The increasing frequency of meiotic abnormalities in virus infected plants was reported by Kaul. (1986).

The pollen sterility of virus infected plants was higher than that of normal plants. It may be due to the incidence of higher frequency of meiotic abnormalities in infected plants. Similar results were also reported by Reddy and Rao (1982) and Peterson (1958) in C. апnиит.

The pollen sterility of virus infected plants were higher than that of normal plants. It may be due to the incidence of higher frequency of meiotic abnormalities in infected plants. Similar results were also reported by Reddy and Rao, (1982) in C. апnиum.The present investigation revealed a negative impact of virus infection on meiotic cell division of the Papaya plants.

Table No.1:- Pollen viability in healthy plants of Carica papaya (L.).(P.G. = Pollen grains; PV = Pollen viability.)

\begin{tabular}{|c|c|c|c|c|c|c|}
\hline \multirow[t]{2}{*}{ Replications } & & \multirow{2}{*}{$\begin{array}{c}\text { No. of viable } \\
\text { P.G. }\end{array}$} & \multirow{2}{*}{$\begin{array}{l}\text { Total Sterile } \\
\text { P.G. }\end{array}$} & \multicolumn{2}{|c|}{ No. of sterile pollen grains } & \multirow[t]{2}{*}{ P.V.\% } \\
\hline & $\begin{array}{c}\text { Total of P.G. } \\
\text { counted }\end{array}$ & & & Empty & Shrunken & \\
\hline 01. & 474 & 460 & 14 & 10 & 04 & 97.05 \\
\hline 02. & 401 & 390 & 11 & 08 & 03 & 97.25 \\
\hline 03. & 523 & 506 & 17 & 09 & 08 & 96.75 \\
\hline 04. & 867 & 839 & 28 & 19 & 09 & 96.77 \\
\hline 05. & 701 & 680 & 21 & 14 & 07 & 97.00 \\
\hline 06. & 218 & 210 & 08 & 02 & 06 & 96.33 \\
\hline 07. & 301 & 290 & 11 & 04 & 07 & 96.34 \\
\hline 08. & 424 & 410 & 17 & 08 & 09 & 96.01 \\
\hline 09. & 203 & 198 & 05 & 02 & 03 & 97.53 \\
\hline 10. & 542 & 516 & 26 & 16 & 10 & 95.20 \\
\hline Total & 4657 & 4499 & 158 & $\begin{array}{c}92 \\
58.22 \%\end{array}$ & $\begin{array}{c}66 \\
41.78 \%\end{array}$ & $\begin{array}{c}96.60 \\
\%\end{array}$ \\
\hline
\end{tabular}

On an average pollen viability is $96.60 \%$ in healthy plants.

Table No. 2:- Pollen viability in Carica papaya infected by P.R.S.V.(P.G. = Pollen grains; P.V= Pollen viability).

\begin{tabular}{|c|c|c|c|c|c|c|}
\hline \multirow[t]{2}{*}{ Replications } & \multirow{2}{*}{\begin{tabular}{|l|} 
\\
Total no.of \\
P.G.counted
\end{tabular}} & \multirow{2}{*}{$\begin{array}{l}\text { Total } \\
\text { No.of } \\
\text { viable } \\
\text { P.G. }\end{array}$} & \multirow[b]{2}{*}{$\begin{array}{l}\text { Total no.of Sterile } \\
\text { P.G. }\end{array}$} & \multicolumn{2}{|c|}{$\begin{array}{l}\text { No. of sterile pollen grains } \\
\text { P. G. }\end{array}$} & \multirow[t]{2}{*}{ P.V.\% } \\
\hline & & & & Empty (\%) & $\begin{array}{l}\text { Shrunken } \\
(\%)\end{array}$ & \\
\hline 01. & 636 & 475 & 161 & 116 & 45 & 74.68 \\
\hline 02. & 819 & 630 & 186 & 135 & 54 & 76.92 \\
\hline 03. & 480 & 376 & 104 & 68 & 36 & 78.33 \\
\hline 04. & 544 & 418 & 126 & 80 & 46 & 76.83 \\
\hline 05. & 722 & 536 & 186 & 128 & 58 & 74.23 \\
\hline 06. & 832 & 605 & 227 & 132 & 95 & 72.71 \\
\hline 07. & 467 & 348 & 119 & 78 & 41 & 74.51 \\
\hline 08. & 1070 & 732 & 338 & 198 & 140 & 68.41 \\
\hline Total $=$ & 5570 & 4120 & 1450 & $935(64.50)$ & $515(35.50)$ & 73.96 \\
\hline
\end{tabular}

On an average pollen viability is $73.66 \%$ in diseased plants. 
Table No.3:- Meiotic abnormalities and pollen sterility in normal and virus infected plant species.

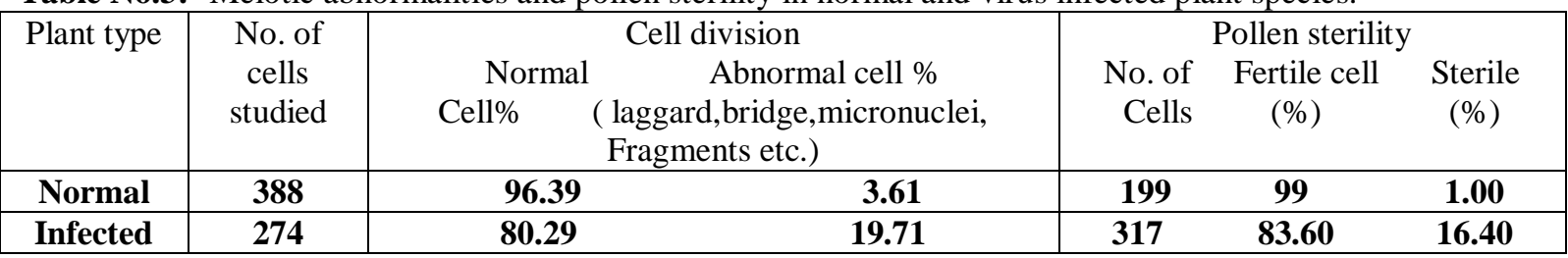

\section{Conclusions:-}

The high pollen viability $96.60 \%$ in healthy plants and low pollen viability $(73.96 \%)$ in disease plants suggests that probably there was checkpoint or nuclear restitution events during meiosis which leads to inviability.The defect in cell division shows that if normal division process deviated then plants cannot grow properly. The present investigation revealed a negative impact of virus infection on cell division. Deviation in pollen fertility immediately affected the fruit settings. Thus it establishes a basic cytological relationship between host and viral pathogen to understand the physiology of parasitism for disease management.

\section{Acknowledgement:-}

I am thankful to Principal and Head Department of Botany for providing lab facilities and moral support to do the present work smoothly.

\section{References:-}

1. ALEXANDER M. P., 1969 - Diferential staining of aborted and nonaborted pollen. Stain Technology, 44:117122.

2. Belling. 1926. Iron acetocarmine method of fixing and staining chromosomes. Biology Bulletin 58: 355-363.

3. Bawden, F.C. (1964), Plant viruses and virus diseases. The Ronald Press Co. New York.

4. Clinch, P. (1932). Cytological studies of potato plants affected with certain virus diseases.Scient. Proc.Roy.Dublin. Soc., 15: 143 - 172.

5. Caldwell, J. 1952. Study of meiosis in virus infected tomato plants. Ann. Appl. Biol. 39: 98-102.

6. Diaz, M. and C. Pavan. 1965. Chromosomal anomalies due to virus infection in different crop.plants. Proc. Natl. Acad. Sci. Wash. 54: 1321-1327.

7. Kostoff, D. 1933. Meiotic study in virus infected tobacco plants. Genetica 15: 103-114.

8. Kaul, B.L. 1968. A study of meiosis in virus infected Datura quarcifolia. Cytologia 33: 17-20.

9. Khurana, S.M.P. (1968). Studies on virus disease of papaya (carica papaya L.) in Gorakhpur. Ph. D. thesis, Uni. Of Gorakhpur, India.

10. Khurana, S.M. Paul (1974). Studies on three virus diseases of Papaya in Gorakhpur, India. Proc. XIX int. Hort.Congr. , wars Zawa, Poland, 7:260 (Abstr.)

11. Mc Lintok B. 1992. A method of making acetocarmine smears permanent. Strain Technology 4: 53-60.

12. Muniyappa, V. (2003) Plant disease Scenario in south India. Indian phytopath, 56:328.

13. Reddy, S.S. and G.M. Rao. 1982. Cytogenetic effects of agricultural chemicals. III. Effects of hormones"Planofixand Lihocin" on chromosomal mechanism in relation to yield and yield components in chilli (Capsicum anпиum L.).

14. Rawlins, T.E. and Tompkins, C.M.(1936). Studies on the effect of carborandum as abrasive in plant virus inoculation. Phytopathology, 26:578. 66.

15. Swaminathan, M.S., T. Ninan and M.L. Magoon. 1959. Cytological effects of mosaic virus in chillis.Genetica. 30: 63-69.

16. Wilkinson, J. 1953. Cytological abnormalities in tomato affected by virus. Nature. 30: 658-659.

17. Willey, R.I. (1971). Microtechniques: A laboratory Guide. McMillan Publishing Co.INC.,New York.

18. Wintermantel,-W-M (2005). Co-infection of Beet mosaic virus with Beet yellowing viruses leads to increased symptom expression on sugar beet. Plant- Disease. 2005;89(3): 325-331.

19. Yadav,H and P K Yadav Studies on Behavior of Chromosomes during Meiosis Induced by Chilli Mottle Virus Disease in Capsicum annum L. Research Journal of Agricultural Sciences 2011,2(2): 331-333 